\title{
A CHURCH OF STRANGERS: THE UNIVERSAL CHURCH OF THE KINGDOM OF GOD IN SOUTH AFRICA
}

Ilana van Wyk

Wits University Press. pp $x v+280$

ISBN 078-86814-809-7

\section{Reviewed by Graham Duncan}

Faculty of Theology

University of Pretoria

graham.duncan@up.ac.za

This book is a powerful and engaging ethnographic study and exposé of a church of Brazilian origin, the Universal Church of the Kingdom of God in South Africa (UCKG), which has taken root in South Africa as a feature of the post-apartheid era. It is part of the rapidly growing Pentecostal movement, yet is quite distinctive from it in the sense that it denies the expression of emotions and eschews the formation of community which are fundamental to Christian community. Its markers are demonology and angelology which are basic to the work of spiritual warfare. As is common in gnostic bodies which claim to possess arcane special knowledge, it is dismissive of mainline Christianity and African Traditional Religion (ATR). It is neither biblically based nor Christocentric. What it does have in common with similar churches is the prioritisation of material rather than spiritual growth as a source of blessing in the forms of wealth, health, social harmony and happiness. Pastors are money-makers while congregation members are pressed into making large donations, even when this means the denial of basic family subsistence needs.

Obedience is required to the institution rather than to the call of the Holy Spirit. Its organisation is eclectic yet basically hierarchical, exercising total control often by remote means and micro-management, thus denying the manifestation and operation of charismatic leadership. This indicates the presence of worldly features and multi-national corporate strategies. Control is often exercised by means of the spread of gossip, hearsay and rumour. From their entry into the church, members

\section{UNISA}


find themselves involved in spiritual warfare against the forces that militate against wealth accumulation. They become empowered with technologies to overcome such threats. This has been well described as a 'community of exceptional dysfunction' or a client community.

The draw of the prosperity gospel is the equivalent of forced conversion for poor (and not so poor) people. But some disconcerting practices are highlighted. Deaths in the congregation are not announced, nor are funeral arrangements, and funerals are localised away from worship centres. Such practices are distinctly unAfrican but go unchallenged.

Contrary to the long striven for achievements of the missionary movement, the UCKG produces fast foods in globally localised localities. This is its form of indigenisation/inculturation. Its methodology is thoroughly pragmatic and not necessarily founded on Christian values. This is an ahistorical approach to faith in which 'the UCKG inhabits the world view of its target audience to such an extent that local people recognised its potential impact on the very fabric of their society and literally "spoke back" (page 241).

In this valuable study the UCKG is revealed as a body which does not value or promote community. It does not care for its members. It preys on the poor and vulnerable. It seeks out the poor and impoverishes them further by persuading them to become indebted to others as a sign of faithfulness. In this respect, it is antigospel and is life-denying rather than life-fulfilling (John 10:10). The author is to be commended for her courage in pursuing this study in the face of considerable danger to herself and her interlocutors. It is rare for a researcher to pursue a study into the internal affairs of a church such as the UCKG. In this, it is to be commended for the insights which are often assumed but seldom evidenced and proven to be true. 